\title{
Lactation Persistency in Bulgarian Murrah Buffalo Cows
}

\author{
P. Penchev and Tz. Peeva*
}

Agricultural Institute - Shumen, 3 Simeon Veliki Blvd., Shumen 9700, Bulgaria

\begin{abstract}
With the objective to establish the lactation persistency and its variability as affected by different factors, the study assigned 953 lactations of 310 Bulgarian Murrah buffalo cows bred on the farm of Agricultural Institute - Shumen within the period 1967-2009. The main method of measurement was the mean post-peak milk yield reduction. The data were processed by the conventional statistical procedure, as well as by the software products LSMLMW and MIXMDL. The persistency of milk yield after reaching peak was established to be relatively high $(89.22 \%)$. Its variance is to a great extent explained by the factors days in milk $(P<0.001)$ and parity $(P<0.001)$, defining favorable effect of increased lactation length, and adverse effect of advancement in lactation order. The significant effect of season of calving $(\mathrm{P}<0.001)$ is expressed in higher lactation persistency in the autumn and winter calvers. The other environmental factor, period, and the genetic factor (individual) are significant at $\mathrm{P}<0.01$, while the effect of productivity level is not. The portion of the peak yield was estimated to be $15.75 \%$ of the lactation productivity, the percentage of the greatest yield drop $11.38 \%$, the persistency ratio between the first and second lactation half $-73.60 \%$.
\end{abstract}

Keywords: Buffaloes, lactation persistency, post-peak drop, effects.

\section{INTRODUCTION}

Lactation persistency is considered an important functional trait since it is associated with health status of dairy animals [1-4], profitability of milk production [5, $6]$, and reproductive efficiency [7, 8]. The variety of methods to measure it is great [9], most of them regarding the monthly reduction after peak yield is reached as best indicator for the ability to maintain relatively high productivity level with the advancement of lactation [10].

From selection standpoint, it is noteworthy that in buffaloes there is relatively high variability in lactation persistency [11-13], observed also in our preceding study on lactation curve [14]. The improvement of this trait necessitates knowledge of the factors determining its variance. The sources of variability in persistency are associated with heritability, hormonal status, udder morphology, seasonal effects, management, animal health, stress, and nutrition [15]. In different studies such effects on lactation persistency have been subject of research in different conditions worldwide [16-19], as well as in the Bulgarian Murrah [11].

Although those studies have established that persistency and lactation curve are significantly affected by environmental factors, other research works have shown that they are moderately heritable as well $[12,13]$.

The objective herein is to study the persistency of lactation defining the reduction in milk yield after peak

*Address correspondence to this author at the Agricultural Institute - Shumen, 3 Simeon Veliki Blvd., Shumen 9700, Bulgaria, Tel: +359 889808535; Fax: +359 54830455; E-mail: tzonkapeeva@abv.bg in Bulgarian Murrah buffalo cows and the sources of its variability.

\section{MATERIAL AND METHODS}

The study assigns a total of 953 lactations of 310 Bulgarian Murrah buffalo cows bred on the farm of Agricultural Institute - Shumen within the period 19672009. The lactations used consist of at least eight monthly test day records and have milk yield per normal lactation of at least $500 \mathrm{~kg}$. Lactation persistency was measured by one absolute and three complimentary methods:

- Mean monthly post-peak drop (absolute measure):

$P_{M E A N}=100^{*}\left(M_{P+1} / M_{P}+M_{P+2} / M_{P+1}+\ldots+M_{P+6} / M_{P+5}\right) / 6$

$M_{P}$ - milk yield per peak month, which in the majority of cases is second lactation month, in 278 of the cases - third, and in 38 - fourth; hence, the lactations were selected to be of at least eight, nine, and ten test days (months) respectively;

$M_{P+N}-$ milk yield in the $N$-th post-peak month $(N=$ $1 \ldots 6)$

- Percentage of second lactation half out of first:

$P_{\text {HALF }}=100^{*}\left(M_{5-8} / M_{1-4}\right)$

$M_{5-8}$ - total milk yield for fifth to eight month of lactation;

$M_{1-4}$ - total milk yield for first to fourth month of lactation; 
- Percentage of persistency of the greatest drop:

$P_{D R O P}=100-\left[100^{*}\left(M_{P}-M_{M I N}\right) / M_{8}\right]$

$M_{M I N}$ - lowest milk yield test-day record;

$M_{8}$ - total milk yield from first to eight lactation month;

- Percentage of peak out of lactation milk yield:

$P_{P E A K \%}=100^{*}\left(M_{P} / M_{305}\right)$

$M_{305}$ - milk yield per normal lactation (210-305 days).

The pool of data was processed using the software products LSMLMW and MIXMDL [20], the model for $P_{\text {MEAN }}$ and $P_{\text {HALF }}$ being constructed as follows:

$Y_{i, q}=\mu+C O W_{i}+S E A_{j}+P E R_{k}+P A R_{g}+D I M_{l}+L M Y_{q}+$ $e_{i j k g l, q}$,

including the random factor individual $\left(\mathrm{COW}_{i}, \quad i=\right.$ $1 \ldots 310)$ and the fixed season of calving $\left(S E A_{j}, j=1 \ldots 4\right)$, period of calving $\left(P E R_{k}, k=1 \ldots 8\right)$, parity $\left(P A R_{g}, g=\right.$ $1 \ldots 3)$, days in milk $(D I M l, l=1 \ldots 4)$, and lactation milk yield $\left(L M Y_{q}, q=1 \ldots 3\right)$. For $P_{D R O P}$ and $P_{P E A K} \%$ the factor milk yield $\left(L M Y_{q}\right)$ was excluded from the model.

To establish phenotypic variation, the data were also processed using the conventional statistical procedure.

\section{RESULTS AND DISCUSSION}

Principally, the idea of measuring persistency of lactation is to express a complex individual characteristic of an animal in one mathematical value, so to use it for further research or implement it in selection. That is why the methods employed are rather variable [9], in correspondence with the peculiarities of the herd and the policy of the farm. But whatever the measurement approach, it should be borne in mind that lactation persistency is not to be considered independently but together with the other characteristics of the lactation curve. Specificity of the lactation of the Bulgarian Murrah buffaloes is to usually attain early peak, the yield decline being a major part of it $[11,14,21]$. Hence, the present study employs as an absolute parameter the mean yield reduction for a constant of post-peak monthly records (six), giving a weighed value for each lactation. Similar is the reason to use the complimentary measure $P_{D R O P}$ - a general expression of the total decline, also weighed on the basis of fixed days in milk. The other complimentary methods involve also the first lactation months, $P_{\text {HALF }}$ being indicative for the milk yield in the most productive lactation part, in view of the fact that some buffaloes peak in the third and even in the fourth lactation month; and $P_{P E A K}$ characterizing the peak productivity itself in comparison to the milk yield per normal lactation, which is another more general aspect of persistency.

The results of the statistical data processing (Table 1 ) indicate the mean post-peak persistency $\left(P_{\text {MEAN }}\right)$ is $83.68 \%$ with relatively high coefficient of variability $\mathrm{CV}=22.26$. The established persistency mean is approximate to the values from a similar measure of persistency reported for some buffalo breeds [16, 2224], and is much higher than that for the Egyptian Buffalo [13]. Nevertheless, in comparison to their results, the phenotypic variability resulted herein is greater which is to be considered in selection.

The variability within lactations of different order (Table 2) is normally lower than that for the general pool of data. Despites, compared to the coefficients established by the above authors [13, 16, 22-24], it is still relatively high. As the data show, the phenotypic value of the post-peak persistency is highest at first lactation, corresponding to a milk yield of $1677.3 \mathrm{~kg}$. The rate of persistency relative decrease from first to third-plus lactation (5.2\%) is comparable with the respective increase in lactation milk yield $(7.8 \%)$.

The milk yield from fifth to eight month is $63.87 \%$ of that for the first four test days (Table 1), and the persistency percentage from peak to lowest monthly

Table 1: Phenotypic Means of Lactation Persistency $(n=953), \%$

\begin{tabular}{|c|c|c|c|}
\hline Persistency measure & $\overline{\mathrm{x}}$ & $\mathbf{\pm S} \overline{\mathrm{x}}$ & $\mathbf{C V}$ \\
\hline \hline Post-peak mean monthly reduction $\left(P_{\text {MEAN }}\right)$ & 83.68 & \pm 0.60 & 22.26 \\
\hline First/second lactation half $\left(P_{\text {HALF }}\right)$ & 63.87 & \pm 0.72 & 34.82 \\
\hline Peak/minimal monthly yield $\left(P_{D R O P}\right)$ & 87.02 & \pm 0.34 & 11.99 \\
\hline Peak/lactation yield $\left(P_{P E A K \%}\right)$ & 16.16 & \pm 0.11 & 20.62 \\
\hline
\end{tabular}


Table 2: Phenotypic Means of Post-Peak Monthly Reduction ( $\left.P_{M E A N}\right)$ and the Corresponding Milk Yield by Order of Lactation

\begin{tabular}{|c|c|c|c|c|c|c|c|}
\hline \multirow[t]{2}{*}{ Lactation } & \multirow[t]{2}{*}{$\mathbf{n}$} & \multicolumn{3}{|c|}{$P_{\text {MEAN, }} \%$} & \multicolumn{3}{|c|}{ 305-d lactation milk yield, kg } \\
\hline & & $\bar{x}$ & $\pm S^{-}$ & CV & $\overline{\mathrm{x}}$ & $\pm S \bar{x}$ & CV \\
\hline First & 299 & 91.70 & \pm 0.457 & 8.62 & 1677.3 & \pm 25.52 & 26.30 \\
\hline Second & 224 & 87.24 & \pm 0.459 & 7.87 & 1804.4 & \pm 32.47 & 26.93 \\
\hline Third+ & 430 & 86.94 & \pm 0.440 & 10.49 & 1808.1 & \pm 28.11 & 32.24 \\
\hline
\end{tabular}

yield comes to $87.02 \%$, i.e. the portion of the greatest drop is $12.98 \%$ out of the eight-month productivity. The percentage of the peak yield out of the normal-lactation milk yield is $16.16 \%$. $P_{D R O P}$ has a markedly lower variation $(11.99 \%)$, presumably due chiefly to the low variability in a shorter period like peak month [14], as compared to that in the four-month periods predetermining the high coefficient of variation of $P_{\text {HALF }}$ $(C V=34.82)$

The results of the analysis of variance (Table 3 ) show that days in milk and parity explain greatest part of the variance of persistency, the F-values for the absolute measure of persistency being $F=30.89$ $(\mathrm{P}<0.001)$ and $\mathrm{F}=21.54(\mathrm{P}<0.001)$ respectively. For the range of variability of $P_{M E A N}$ among parities of different order can be judged from the phenotypic variation in the overall pool of data (Table 1) as compared with that within lactation orders (Table 2). The effect of lactation duration on $P_{\text {HALF }}$ is not so markedly expressed but still highly significant $(\mathrm{P}<0.001)$, while the F-values concerning $P_{D R O P}$ and $P_{P E A K \%}$ are highest $-\mathrm{F}=52.29(\mathrm{P}<0.001)$ and $\mathrm{F}=64.16$ $(P<0.001)$. Earlier evidences of persistency significantly affected by parity $[19,25]$ and days in milk $[13,14,16$, 26] are also present.

The results in the table indicate that productivity level has no significant effect on the post-peak yield reduction $\left(P_{M E A N}\right)$, while it affects the ratio between the two lactation halves $\left(P_{\text {HALF }}\right)(\mathrm{P}<0.001)$. There are studies showing significant effect of lactation milk yield on persistency of buffalo cows [16, 25], another author reports correlation estimates of 0.19 to 0.27 [22], but Dhaka et al. [27] conclude that the relationship between persistency and productivity could vary in wide range depending on the methods of measure.

Season of calving also exerts marked effect - with high degree of significance on $P_{\text {MEAN }}$ and $P_{\text {HALF }}$ $(\mathrm{P}<0.001)$ and with moderate on $P_{D R O P}$ and $P_{P E A K \%}(\mathrm{P}<$ $0.01)$. The other environmental factor, period of breeding, is a source of specific variability on the absolute measure of persistency $(P<0.01)$, but not on the complimentary measures $(P>0.05)$. Some studies observe pronounced effects of the two environmental factors [16-19], while other do not [11, 13, 24, 28]. This contradiction indicates that the ability of a dairy buffalo to maintain relatively high productivity throughout lactation can be improved by optimization of feeding, management, and udder care.

The genetic factor (individual) plays generally well expressed effect on the variance of persistency, though expressed in low F-values. It is highly significant on the three complimentary parameters $(P<0.001)$ and moderately significant on the main parameter $(P<0.01)$. This is in keeping with the established herein high variability of the persistency parameters, except for $P_{D R O P}$ (Table 1), as well as with the opinion that

Table 3: F-Values from the Analysis of Variance

\begin{tabular}{|c|c|c|c|c|c|c|c|c|c|}
\hline \multirow{2}{*}{$\begin{array}{l}\text { Variables } \\
\text { Buffalo cow }\end{array}$} & \multirow{2}{*}{$\begin{array}{c}\text { df } \\
309\end{array}$} & \multicolumn{2}{|c|}{$\begin{array}{l}\text { Post-peak reduction } \\
\qquad\left(P_{M E A N}\right)\end{array}$} & \multicolumn{2}{|c|}{$\begin{array}{c}\text { First/second lactation } \\
\text { half }\left(\boldsymbol{P}_{\text {HALF }}\right)\end{array}$} & \multicolumn{2}{|c|}{$\begin{array}{c}\text { Peak/minimal monthly } \\
\text { yield }\left(P_{D R O P}\right)\end{array}$} & \multicolumn{2}{|c|}{$\begin{array}{c}\text { Peak/lactation yield } \\
\left(P_{P E A K \%}\right)\end{array}$} \\
\hline & & 1.29 & $* *$ & 1.89 & $* * *$ & 1.61 & $* * *$ & 1.46 & $* * *$ \\
\hline Season of calving & 3 & 6.15 & $* * *$ & 7.70 & $* * *$ & 5.47 & ** & 4.44 & ** \\
\hline Period of calving & 7 & 3.44 & $* *$ & 1.84 & n.s. & 1.72 & n.s. & 1.34 & n.s. \\
\hline Parity & 2 & 21.54 & $* * *$ & 38.57 & $* * *$ & 34.09 & $* * *$ & 33.29 & $* * *$ \\
\hline Days in milk & 3 & 30.89 & $* * *$ & 9.72 & $* * *$ & 52.29 & $* * *$ & 64.16 & $* * *$ \\
\hline Productivity level & 2 & 0.47 & n.s. & 8.95 & $* * *$ & \multicolumn{2}{|c|}{-} & \multicolumn{2}{|c|}{ - } \\
\hline
\end{tabular}

Significance of F-test: ${ }^{* *}-\mathrm{P}<0.001 ;{ }^{* \star}-\mathrm{P}<0.01 ;{ }^{*}-\mathrm{P}<0.05 ;$ n.s. $-\mathrm{P}>0.05$. 
persistency of lactation productivity is an individual characteristic of dairy animals determined physiologically $[22,29,30]$ and genetically $[12,13]$. According to Ludwick et al. [31], a major portion of its variation is a result of the inheritance of genes which govern the development and the function of various endocrine glands, the influence of sire or dam being detectable in this aspect.

Table 4 presents the results of the effects of the three most pronounced sources of variance on lactation persistency. The values for the levels of the factor lactation length indicate that increasing days in milk results in higher persistency. In the case of shortest days in milk the absolute measure of persistency is lowest $(83.28 \%, \mathrm{P}<0.001)$, and in the case of longest days in milk - highest $(93.70 \%$, $\mathrm{P}<0.001$ ), the total relative difference coming to $11.8 \%$. To similar extent is affected $P_{D R O P}$, all the differences being significant at $P<0.001$ and $P<0.01$. Even better expressed is the overall relative difference concerning
$P_{\text {HALF }}(17.5 \%$, at $\mathrm{P}<0.001$ and $\mathrm{P}<0.05)$ and especially $P_{\text {PEAK\% }}(29.0 \%$, at $\mathrm{P}<0.001)$. A number of studies on buffaloes also indicate that the longer lactations are more persistent [16, 19, 32]. Nevertheless, it should be born in mind that in such cases the productivity in the conclusive part of the lactation is comparatively high [14], which should not mislead to postponing drying-off.

The results regarding the effect of parity (Table 4) are correspondent to those in Table $\mathbf{2}$. It is obvious that the main persistency parameter is adversely affected by the factor - the value for first lactation (92.27\%) is relatively higher by 4.5 and 5.4 percent than second and third-plus lactation $(\mathrm{P}<0.001)$. Such a high percentage of persistency at first lactation, can be explained with the relatively low $(P<0.001)$ peak yield $\left(P_{P E A K \%}\right)(14.57 \%)$, compared to second $(15.82 \%)$ and third-plus lactation (16.87\%). Even more remarkable is the expression of the effect of parity on $P_{\text {HALF }}$, where first lactation is by 12.6 and 18.1 percent relatively superior $(P<0.001)$. The same applies to lesser extent

Table 4: Effect of the Factors Days in Milk, Parity, and Season of Calving

\begin{tabular}{|c|c|c|c|c|c|c|c|c|c|}
\hline \multirow[t]{2}{*}{$\begin{array}{l}\text { Factors and } \\
\text { levels }\end{array}$} & \multirow[t]{2}{*}{$\mathbf{n}$} & \multicolumn{2}{|c|}{$\begin{array}{l}\text { Post-peak mean } \\
\text { monthly reduction } \\
\left(\boldsymbol{P}_{\text {MEAN }}\right)\end{array}$} & \multicolumn{2}{|c|}{$\begin{array}{c}\text { First/second lactation } \\
\text { half }\left(\boldsymbol{P}_{\text {HALF }}\right)\end{array}$} & \multicolumn{2}{|c|}{$\begin{array}{c}\text { Peak/minimal monthly } \\
\text { yield }\left(P_{D R O P}\right)\end{array}$} & \multicolumn{2}{|c|}{$\begin{array}{c}\text { Peak/lactation yield } \\
\left(P_{P E A K \%}\right)\end{array}$} \\
\hline & & $\mathbf{x}$ & \pm SE & $\mathbf{x}$ & $\pm \mathrm{SE}$ & $\mathbf{x}$ & \pm SE & $\mathbf{x}$ & $\pm \mathrm{SE}$ \\
\hline $\begin{array}{l}\text { Overall LS- } \\
\text { mean }\end{array}$ & 953 & 89.22 & \pm 0.31 & 73.60 & \pm 0.84 & 88.62 & \pm 0.24 & 15.75 & \pm 0.12 \\
\hline \multicolumn{10}{|c|}{ Days in milk } \\
\hline 1. $210-270 \mathrm{~d}$ & 209 & 83.28 & \pm 0.72 & 67.04 & \pm 1.65 & 83.83 & \pm 0.46 & 18.41 & \pm 0.24 \\
\hline 2. $271-330 \mathrm{~d}$ & 373 & 89.90 & \pm 0.52 & 72.42 & \pm 1.22 & 88.52 & \pm 0.36 & 16.19 & \pm 0.18 \\
\hline 3. $331-390 d$ & 201 & 90.01 & \pm 0.62 & 75.01 & \pm 1.41 & 89.75 & \pm 0.43 & 14.67 & \pm 0.22 \\
\hline 4. over $390 \mathrm{~d}$ & 170 & 93.70 & \pm 0.74 & 79.93 & \pm 1.65 & 92.36 & \pm 0.50 & 13.74 & \pm 0.25 \\
\hline t-test & & \multicolumn{2}{|c|}{$1-[2,3,4]^{\star * *} ; 4-[2,3]^{* * *}$} & \multicolumn{2}{|c|}{$\begin{array}{c}1-[2,3,4]^{\star \star \star} ; 2-[3]^{*} \\
4-[2,3]^{\star \star *}\end{array}$} & \multicolumn{2}{|c|}{$\begin{array}{c}1-[2,3,4]^{\star \star *} ; 2-[3]^{\star *} \\
4-[2,3]^{\star \star *}\end{array}$} & \multicolumn{2}{|c|}{$* * *$} \\
\hline \multicolumn{10}{|c|}{ Parity } \\
\hline First & 299 & 92.27 & \pm 0.56 & 81.97 & \pm 1.29 & 90.96 & \pm 0.39 & 14.57 & \pm 0.20 \\
\hline Second & 224 & 88.12 & \pm 0.55 & 71.67 & \pm 1.28 & 88.41 & \pm 0.38 & 15.82 & \pm 0.19 \\
\hline Third+ & 430 & 87.27 & \pm 0.52 & 67.16 & \pm 1.22 & 86.47 & \pm 0.37 & 16.87 & \pm 0.19 \\
\hline t-test & & \multicolumn{2}{|c|}{$1-[2,3]^{* * *}$} & \multicolumn{2}{|c|}{$* * *$} & \multicolumn{2}{|c|}{$* * *$} & \multicolumn{2}{|c|}{$* * *$} \\
\hline \multicolumn{10}{|c|}{ Season of calving } \\
\hline 1. Spring & 220 & 88.13 & \pm 0.63 & 71.54 & \pm 1.42 & 88.08 & \pm 0.44 & 15.85 & \pm 0.22 \\
\hline 2. Summer & 359 & 87.65 & \pm 0.52 & 69.80 & \pm 1.21 & 87.65 & \pm 0.37 & 16.12 & \pm 0.18 \\
\hline 3. Autumn & 216 & 90.30 & \pm 0.62 & 74.50 & \pm 1.41 & 88.70 & \pm 0.43 & 16.01 & \pm 0.22 \\
\hline 4. Winter & 158 & 90.82 & \pm 0.72 & 78.55 & \pm 1.60 & 90.04 & \pm 0.49 & 15.03 & \pm 0.25 \\
\hline t-test & & \multicolumn{2}{|c|}{$4-[1,2]^{\star \star *} ; 3-[1,2]^{\star \star *}$} & \multicolumn{2}{|c|}{$\begin{array}{c}1-[4]^{\star \star \star} ; 2-[3,4]^{\star \star *} \\
3-[4]^{\star *} ; 1-[2]^{\star}\end{array}$} & \multicolumn{2}{|c|}{$4-[1,2]^{\star * *} ; 4-[3]^{\star *}$} & \multicolumn{2}{|c|}{$4-[1,2,3]^{* * *}$} \\
\hline
\end{tabular}

Significance of t-test: ${ }^{\star \star \star}-P<0.001 ;{ }^{* \star}-P<0.01 ;{ }^{*}-P<0.05$ 
to $P_{D R O P}$, also with significance of all differences $(P<0.001)$. These results are commensurate with the observation of other authors [19, 25] that after first lactation buffalo cows improve their productivity chiefly because of the increased peak milk yield, lactation declining more abruptly afterwards to end up at a similar productive level.

The results indicate that more persistent are the lactations starting in winter and autumn, the differences concerning $P_{M E A N}$ being relatively small but highly significant - in the range of $3.5 \%(P<0.001)$. Similar is the range among the values of $P_{D R O P}$ but with outstandingly highest estimate for winter $(P<0.01$ and $P<0.001)$. Greater are the differences expressing the superiority of the buffaloes calving in winter regarding peak yield $(7.3 \%, \mathrm{P}<0.001)$, and especially those regarding the ratio between the lactation halves (11.1\%, $\mathrm{P}<0.001$ and $\mathrm{P}<0.01)$. The higher persistency of the buffalo cows calving in winter and also in autumn could be accounted to the fact that the post-peak lactation decline happens in that part of the year that provides for many high-quality fodders and favorable weather conditions. Likewise, [16, 33] also observed that the in-season calving buffaloes are more persistent.

The established herein relatively high variability of the persistency parameters, the significant effect of both non-genetic and genetic factors on them indicate that lactation persistency in dairy buffaloes can be improved through optimization of feeding and management, but also through selection with respect to the other important parameters of lactation curve and productive performance.

\section{CONCLUSIONS}

The mean post-peak persistency of lactation in the Bulgarian Murrah buffaloes was established to be $89.2 \%$. The variance of lactation persistency is to a great extent explained by the factors days in milk $(P<0.001)$ and parity $(P<0.001)$, defining favorable effect of increased lactation length, and adverse effect of advancement in lactation order. The significant effect of season of calving $(P<0.001)$ is expressed in higher lactation persistency in the buffaloes calving in winter and autumn. Peak yield was estimated to be $15.8 \%$ of lactation productivity.

\section{REFERENCES}

[1] Swalve H. Theoretical basis. J Dairy Sci 2000; 83: 1115-24. http://dx.doi.org/10.3168/jds.S0022-0302(00)74977-0
[2] Jakobsen J, Madsen P, Jensen J, Peersen J, Cristiensen LG, Sorensen DA. Genetic parameters. J Dairy Sci 2002; 85: 1607-16.

http://dx.doi.org/10.3168/jds.S0022-0302(02)74231-8

[3] Harder B, Bennewitz J, Hinrichs D, Kalm E. Genetic parameters. J Dairy Sci 2006; 89: 3202-12. http://dx.doi.org/10.3168/jds.S0022-0302(06)72595-4

[4] Appuhamy JADRN, Cassell BG, Cole JB. Phenotypic and genetic. J Dairy Sci 2009; 92: 1785-95. http://dx.doi.org/10.3168/jds.2008-1591

[5] Sölkner J, Fuchs W. A comparison of different measures. Livest Prod Sci 1987; 16: 305-19. http://dx.doi.org/10.1016/0301-6226(87)90001-7

[6] Dekkers JCM, Jamrozik J, ten Hag JH, Schaeffer LR, Weersink A. Genetic and economic evaluation of persistency in dairy cattle. In: Groen AF et al., editors: International Workshop on Genetic Improvement of Functional Traits in Cattle; 1996: Jan 21-23, Gembloux, Belgium. Bulletin: International Bull Evaluation Service, SLU, Uppsala, Sweden 1998: 12: 97-102.

[7] Muir BL, Fatehi J, Schaeffer LR. Genetic relationships. J Dairy Sci 2004; 87: 3029-37.

http://dx.doi.org/10.3168/jds.S0022-0302(04)73435-9

[8] Atashi H, Sharbabak MM, Sharbabak HM. Environmental factors affecting the shape components of the lactation curves in Holstein dairy cattle of Iran. Livest Res Rural Dev 2004; Volume 21, Article \#60. [cited 2012 Feb 14]: Available from: http://www.Irrd.org//rrd21/5/atas21060.htm

[9] Gengler N. Persistency of lactation. Interbull Bulletin 1996; 12: 87-96

[10] Jamrozik J, Jansen G, Schaeffer LR, Liu Z. Analysis of persistency I. Interbull Bull 1998; 17: 64-9.

[11] Peeva Tz, Vankov K, Vasilev M. Persistency index. Zhivotnovadni Nauki 1988; 25 (5): 10-5.

[12] Geetha E, Chakravarty AK, Vinaya Kumar K. Genetic persistency. Asian-Aust J Anim Sci 2006; 19: 1696-701.

[13] Elmaghraby MMA. Lactation persistency. Lucrări Ştiinţifice 2009; 53: 242-9.

[14] Penchev P, Boichev M, llieva Y, Peeva Tz. Effect of different factors. Slovak J Anim Sci 2011; 44: 103-10.

[15] Pulina G, Nudda A, Macciotta NPP, Battacone G, Rassu SPG, Cannas A. Non-nutritional factors. Ital J Anim Sci 2006; 6: $115-41$.

[16] Chaudhry HZ, Khan MS, Mohiuddin G, Mustafa MI. Persistency of lactation. Intern J Agric Biol 2000; 3: 207-9.

[17] Amin AA. Test-day model. Arch Tierz Dummerstorf 2003; 46: 35-45.

[18] Macciotta NPP, Dimauro C, Catillo G, Coletta A, CappioBorlino A. Factors affecting individual. Livestock Sci 2006 104: 33-7. http://dx.doi.org/10.1016/j.livsci.2006.03.001

[19] Anwar M, Cain PJ, Rowlinson P, Khan MS, Abdullah M, Babar ME. Factors affecting the shape. J Zool Suppl Ser 2009; 9: 201-7.

[20] Harvey WR. User's Guide for LSMLMW and MIXMDL, Mixed Model Least Squares and Maximum Likelihood Computer Program, PC version 2, Ohio State University, Columbus 1990.

[21] Polihronov D, Boikovski S, Peeva Tz. Some regularities. Zhivotnovadni Nauki 1997; 14(6): 25-9.

[22] Shah SSH. Studies on the persistency of lactation in Nili-Ravi buffaloes. M. Sc. Thesis, Dept. Anim. Breed. Genet., Univ. Agric., Faisalabad 1990.

[23] Zakariyya M, Babar ME, Yaqoob M, Lateef M, Ahmad T, Bilal BQ. Environmental factors. Pak J Agric Sci 1995; 32: 249-55. 
[24] Tekerli M, Kucukkebabci M, Akalin NH, Kocak S. Effects of environmental factors. Livest Prod Sci 2001; 68: 275-81. http://dx.doi.org/10.1016/S0301-6226(00)00240-2

[25] Catillo G, Macciotta NPP, Carretta A, Cappio-Borlino A. Effects of age. J Dairy Sci 2002; 85: 1298-306. http://dx.doi.org/10.3168/jds.S0022-0302(02)74194-5

[26] Gajbhiye PU, Tripathi VN. Factors affecting. Indian J Anim Prod Manag 1999; 15: 11-3.

[27] Dhaka SS, Chaudhry SR, Pander BL. Relationship between persistency and production efficiency attributes in Murrah buffaloes. In: Proceedings 6th World Congress on Genetics Applied to Livestock Production; 1998: Jan 11-16; Armidale, NSW, Australia: International Committee for World Congress on Genetics Applied to Livestock Production 1998; 24: 47780.
[28] Dahama RS, Malik PS. Inheritance of peak. Indian Vet Med J 1991; 15: 202-6.

[29] Capuco AV, Ellis SE, Hale SA, et al. Lactation persistency. J Anim Sci 2003; 81(Suppl. 3): 18-31.

[30] Leclerc H, Duclos D, Barbat A, Druet T, Ducrocq V. Environmental. Animal 2008; 2: 344-53.

[31] Ludwick TM, Petersen WE, Fitch JB. Some genetic. J Dairy Sci 1943; 26: 447-55 http://dx.doi.org/10.3168/jds.S0022-0302(43)92740-7

[32] Metry GH, Mourad KA, Wilk JC, McDaniel BT. Lactation curves. J Dairy Sci 1994; 77: 1306-14. http://dx.doi.org/10.3168/jds.S0022-0302(94)77070-3

[33] Das A, Das D, Goswami RN, Bhuyan D. Persistency of milk yield. Buffalo Bull 2007; 26: 316-39. 